\title{
A Life in Science: Twenty Reviews, Research Articles, Commentaries, and Reflections on Peter Doherty's Scientific Contributions and Mentorship
}

\author{
David L. Woodland
}

$\mathbf{I}_{\mathrm{i}}^{\mathrm{N}}$ N 1973, Peter Doherty and Rolf Zinkernagel were trying to understand why different strains of mice responded differently to infection with lymphocytic choriomeningitis virus infection. By collecting a large panel of different mouse strains, they were able to link cytotoxic T lymphocyte (CTL) responses to the virus with the mouse major histocompatibility complex (MHC). Specifically, they made the key observation that CTL could only recognize infected cells that shared the same MHC haplotype, leading to the coining of the term "MHC restriction." The obvious explanation for this phenomenon was that there must be two receptors-one for the viral antigen and one for the MHC molecule. But it turned out that the less popular "altered self" model, involving only one $\mathrm{T}$ cell receptor, was the correct one. This finding was amazing, as it did not fit with traditional concepts of receptor-ligand interaction.

The discovery of MHC restriction led to Peter Doherty and Rolf Zinkernagel being awarded the 1996 Nobel Prize in physiology or medicine. This new understanding of how $\mathrm{T}$ cells recognized foreign, and self, antigens unleashed major advances in our understanding of immunity in general and is the foundation of many of today's cutting-edge approaches to treat disease. It was noted by Dr. Barry Rouse that "The prize was especially pleasing to those of us with a veterinary degree since Peter was the first and remains still the only recipient of the accolade" (this issue). For Peter, this discovery was also the genesis of a long and successful career studying the immune response to infection-indeed many more discoveries followed. But perhaps the greater legacy has been the long list of outstanding scientists that he has trained and who continue to amplify his contribution to science.

I was greatly honored when Peter recruited me to the Immunology Department at St. Jude Children's Research Hospital. As a young scientist, I was deeply influenced by his enthusiasm and scientific dedication and was quickly drawn into the wonders of immunity to viral infections. This forged the direction of my future career as a viral immunologist. I also realized that I was one of a group of very successful scientists who could all trace their success back to the training and mentorship that Peter had given them early in their careers. It is with this background that I conceived the idea of putting together a Festschrift to honor Peter's career and mentorship on multiple generations of outstanding research scientists.

The articles in this issue of Viral Immunology were all written by Doherty colleagues, trainees, and laboratory alumni. I left it open as to the type of article to be contributed and the end result is a wonderful mix of 20 reviews, research articles, commentaries, and reflections on Peter's scientific contributions and mentorship.

I want to thank all of the authors for their contributions to this Festschrift honoring Peter. And on behalf of all 20 authors and myself, we thank Peter for his mentorship and guidance in our careers.

Trudeau Institute, Saranac Lake, New York.

(C) David L. Woodland, 2020; Published by Mary Ann Liebert, Inc. This Open Access article is distributed under the terms of the Creative Commons Attribution Noncommercial License (http://creativecommons.org/licenses/by-nc/4.0/) which permits any noncommercial use, distribution, and reproduction in any medium, provided the original author(s) and the source are cited. 